\title{
The cardiovascular system and the biochemistry of grafts used in heart surgery
}

\author{
Suna Aydin ${ }^{1,2}$, Suleyman Aydin ${ }^{3 *}$, Mehmet Nesimi Eren ${ }^{4}$, Ibrahim Sahin ${ }^{3,5}$, Musa Yilmaz ${ }^{3}$, Mehmet Kalayci $^{3}$ \\ and Orhan Gungor ${ }^{1}$
}

\begin{abstract}
Blood is pumped into the cardiac muscle through arteries called the coronary arteries. Over time, the accumulation of cholesterol, coagulation factors, and cells on the walls of these arteries causes the walls to thicken and lose their elasticity, resulting in the development of atherosclerosis. When the blood supply of the heart is diminished by atherosclerosis, it can be restored by bypass surgery, in which atherosclerosis-free vein and/or artery grafts taken from another area of the body are used to replace the atherosclerotic vessels. These biological grafts used in surgery differ in biochemical composition and long-term patency. Although the great saphenous vein (GSV) has been the most popular graft material in revascularization for years, it has recently been superseded by the internal mammarian artery (IMA), which has a lower incidence of recurrence of atherosclerosis. The aim of the present review is briefly to address the structure of the cardiovascular system and blood vessels, and then, in the light recent data, to present the biochemical compositions and individual advantages of the graft materials used to restore an impaired blood supply to the heart.
\end{abstract}

Keywords: Cardiovascular system; Graft; Blood vessels; Coronary artery bypass

\section{Introduction}

\section{The cardiovascular system and the heart}

The major component of the cardiovascular system is the heart, a muscular structure that pumps blood into two distinct circulatory systems, namely the pulmonary circulation that carries blood to and from the lungs, and the systemic circulation that transports blood to and from all the tissues and organs of the body (Norman and Litwack 1997; Skwarek et al. 2006; Aydin 2011). An adult heart is about the size of a person's clenched fist and weighs about 280 to $340 \mathrm{~g}$ in men and 230 to $280 \mathrm{~g}$ in women (Norman and Litwack 1997). The human heart, which beats about 100,000 times a day, pumps 7000 to 8000 liters of blood to a blood vessel network of 96,560 kilometers in the process (Norman and Litwack 1997; About Arrhythmia [homepage on the Internet] (2012)).

The human heart, divided into right and left parts longitudinally, is also separated into ventricles and atria.

\footnotetext{
* Correspondence: saydin1@hotmail.com

${ }^{3}$ School of Medicine, Department of Medical Biochemistry (Firat Hormone Research Groups), Firat University, Elazig 23119, Turkey

Full list of author information is available at the end of the article
}

The heart functions to pump the blood from the venous system to the arterial system (Norman and Litwack 1997; Skwarek et al. 2006). The right part of the heart receives deoxygenated blood from the peripheral tissues through the venae cavae and pumps it into the pulmonary artery and thence the pulmonary circulation. The left part of the heart receives oxygenated blood via the pulmonary veins and then distributes it to all the peripheral tissues through the aorta (Skwarek et al. 2006; Elghobary and Légaré 2010). While the heart is thus employed, the coronary arteries can become constricted due to atherosclerosis and their blood supply is impaired (Elghobary and Légaré 2010; Miller et al. 2010).

Although the fact that constriction of coronary arteries due to atherosclerosis affects human health has been known for at least 3000 years, as evidenced by ancient Egyptian papyri, it has been less than 300 years since angina pectoris was first associated with coronary artery constriction and less than 100 years since the first clinical myocardial infarction was diagnosed (Cullen et al. 2005). Atherosclerosis is characterized by the accumulation of cholesterol, coagulation factors and cells on the vessel wall, weakening the underlying tunica media layer, 
followed by the formation of intimal atheromatous plaques, which bring about a series of complications (Elghobary and Légaré 2010; Miller et al. 2010; Cullen et al. 2005). These plaques cause the vessel walls to thicken, whereby the lumen is narrowed, reducing the blood flow. Although atherosclerosis can affect all arteries, the most commonly injured vessels are the aorta and the coronary and cerebral arteries (Cullen et al. 2005).

A heart with constricted vessels cannot function properly for long: its contraction starts to deteriorate, and this condition needs to be remedied by coronary artery bypass surgery. In this treatment, artery or vein graft materials are used to restore the blood supply to the myocardium, the area affected by atherosclerosis of the coronary artery (Aydin 2011; Elghobary and Légaré 2010). The grafting in this operation is performed by stopping the heart, a "cardiopulmonary bypass"; or, if the grafting is carried out without stopping the heart, or off pump, the procedure is called "beating heart technique" (Skwarek et al. 2006; Creswell et al. 2005).

The aim of this review is briefly to address the structures of the blood vessels in general, and then to present a comparison of the individual advantages of internal mammarian artery (IMA) and great saphenous vein (GSV) grafts, the materials most commonly used for bypass surgery, from biochemical and physiological aspects in the light of recent data.

\section{Blood vessels}

The other components of the cardiovascular system are the blood vessels (Skwarek et al. 2006; Aydin 2011; Cullen et al. 2005). Although blood vessels differ in some ways they display important similarities. The walls of high-pressure vessels (e.g. subclavian arteries) are thicker than those of the vessels that transport blood under lower pressure (e.g. subclavian veins). While the diameters of arteries become smaller at each branching, the diameters of veins increase with each new addition. Even though the wall structure of minor vessels such as capillaries and venules is simpler, all vessel walls are composed of three layers (Tennant and McGeachie 1990). Blood vessels are classified into six groups: arteries, arterioles, veins, venules, capillaries, and lymphatic vessels (Tennant and McGeachie 1990; Gartner and Hiatt 1997; Lafleur et al. 2003). The structures of these vessels will be addressed in general; individual groups of vessels will not be described separately. However, the vessels used for grafting in coronary artery bypass surgery will be dealt with in detail where appropriate in later parts of this review.

\section{The structure of blood vessels}

Blood vessel walls comprise three main strata, namely the tunica intima, tunica media, and tunica adventitia (Figure 1). These three strata are described below (Tennant and McGeachie 1990).

\section{Tunica intima (inner layer)}

The innermost portion of the wall is a single-cell endothelial layer attached to a basal lamina. Among other products, endothelial cells secrete type II, IV and V collagens, laminin, endothelin, nitric oxide, and von Willebrand factor. The subendothelial layer comprises the basal lamina and a loose, fibroelastic band of connective tissue and occasional smooth muscle cells. Both these layers are arranged longitudinally. The membrana elastica interna is the outermost portion of the subendothelial layer, where elastic fibers are concentrated (Tennant and McGeachie 1990; Gartner and Hiatt 1997; Lafleur et al. 2003).

\section{Tunica media (middle layer)}

This layer is composed of smooth muscle cells in a circular arrangement, arranged concentrically on a matrix containing type III collagen with proteoglycans together with elastic fibers and elastic membranes. This layer, which is very well developed in arteries, is formed from extracellular matrix smooth muscle cells. Capillaries and postcapillary venules have no tunica media layer (Tennant and McGeachie 1990; Gartner and Hiatt 1997).

\section{Tunica adventitia (outer layer)}

The outermost layer is composed of collagen and elastic fibrils. In the veins, it consists mainly of smooth muscle.

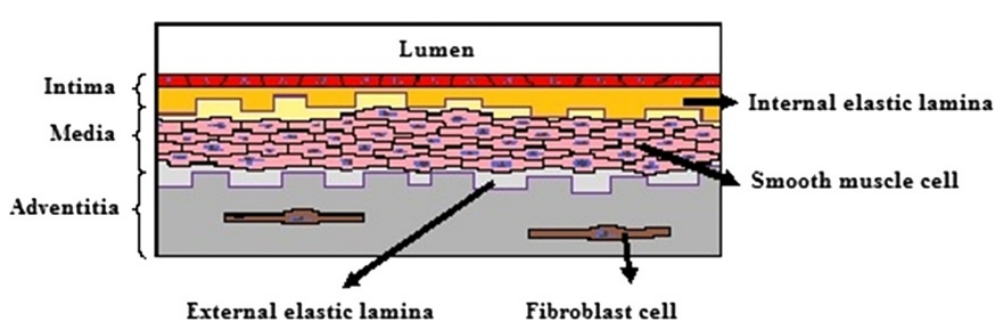

Figure 1 The histological structure of blood vessels. Bloocd vessels are composed of three layers, called (from the lumen outwards) intima, media, and adventitia. 
The elastic fibrils in this area are concentrated to form the membrana elastica externa. The adventitia is the most prominent layer in vein walls (Tennant and McGeachie 1990; Gartner and Hiatt 1997; Lafleur et al. 2003). It extends into the peripheral connective tissue. The walls of large vessels are perfused by small blood vessels, the vasa vasorum, within the adventitia; the adventitia and media layers are too thick to be supplied with nutrients and oxygen by diffusion from the lumen. These vessels are found in smaller numbers in the arteries but are more numerous and can extend to the media layer in the veins. The intima and the innermost part of the media in veins contain no vasa vasorum. Similarly, lymphatic capillaries are found only in the adventitia in arteries, but can reach the media layer in veins (Tennant and McGeachie 1990).

Smooth muscles in blood vessel walls are stimulated by unmyelinated sympathetic nerves (vasomotor nerves), which contain the vasoconstrictor norepinephrin. Cholinergic vasodilator nerves also supply the arteries in skeletal muscle tissue. To effect contraction of the arterial wall smooth muscle, norepinephrin must diffuse into the media layer. Gap junctions between the smooth muscle cells in the tunica media layer enable neurotransmitters to be transported to the inner muscle cells. While there are nerve endings in both the adventitia and media layers in the veins, arteries in general are more richly supplied with nerve cells (Gartner and Hiatt 1997).

\section{Coronary artery bypass surgery graft materials}

A coronary bypass operation is performed on about one million individuals around the world per annum. Gordon Murray, who studied the suturing of mammarian, axillary or carotid arteries on the diseased left anterior descending (LAD) artery in 1953, was the first to show the efficacy of arterial grafts in the coronary circulation (Murray 1953). Four years later, Sidney Smith reported that a segment of saphenous vein from the leg could be used to create a direct bypass from the aorta to the myocardium and could maintain coronary blood circulation (Smith et al. 1957). Currently, arterial grafts, venous grafts, and synthetic grafts are all used in coronary bypass surgery. Grafts are usually classified as autologous and non-autologous. Non-autologous arterial (pig internal thoracic artery (ITA)) and non-autologous venous (v. umbicalis, VSM homograft) grafts are used, but not commonly, so they will not be addressed in this article. Autologous arterial grafts used in coronary bypass surgery include those from the arteria radialis (AR), arteria gastroepiploica dextra (AGED), arteria epigastrica inferior (AEI), a. splenica, a. ulnaris, a. subscapularis, gastric sinistra, and a. circumflexa femoris lateralis (Tennant and McGeachie 1990; Deppe et al. 2013). However, since long-term patency is critical for aorta coronary bypass operations, the LIMA and saphena, which have longer patency, are the two most commonly used graft materials at present (Ferrari and von Segesser 2006). The patency rate for $\mathrm{AR}$, for instance, is reported to be $98 \%$ initially, but decreases to $90 \%$ after one year (Bleiziffer et al. 2007; Erenturk 1997). When the post-operative tenyear patency rates for the left ITA AR and VSM were compared angiographically, they were reported to be 97.5\% for the left ITA $91.6 \%$ for the AR, and $67.1 \%$ for the VSM (Risteski et al. 2006). Therefore, the present study will focus primarily on the left internal mammarian artery (LIMA) and the greater saphenous vein (GSV).

\section{Arteries}

The diameters of the arteries that transport the blood to the capillary beds decrease with increasing distance from the heart. Two arteries branch out from the heart. One is the truncus pulmonalis, which arises from the right ventricle; the other is the aorta, arising from the left ventricle. The aorta, which arises from the upper part of the heart, then makes a turn to the left and descends (Tennant and McGeachie 1990; Lafleur et al. 2003). The internal mammarian artery is the major graft material in heart surgery (Erenturk 1997).

\section{Left internal mammarian artery (LIMA)}

The left internal mammarian artery (LIMA) arises from the early inferior part of the subclavian artery in the medial segment of the anterior scalene muscle. Passing between the clavicula and the first costal cartilage, it descends to the thorax and proceeds along the lateral side of the sternum (Tennant and McGeachie 1990; Gartner and Hiatt 1997). Posteriorly, it is above the pleura and is traversed by the phrenic nerve. It proceeds behind the superior sixth costal cartilage between the intercostal muscles. After it passes the third costal cartilage it moves to the anterior side of the transversus thoracis muscle and then bifurcates into the superior epigastric and musculophrenic arteries at the sixth costal cartilage (Tennant and McGeachie 1990; Gartner and Hiatt 1997; Lafleur et al. 2003). A bypass of the LIMA to the LAD artery is common (Erenturk 1997; Sabik et al. 2008). Use of the left internal thoracic artery instead of the saphenous vein in coronary artery bypass surgery was widely accepted in angiographic studies during the 1980s (Fukui et al. 2010). Similarly, the use of bilateral LIMA as a graft material was reported to improve survival in recurrent myocardial ischemia after coronary bypass (Lytle et al. 1999). When the LIMA is used in coronary artery bypass grafting operations, operative mortality is reduced, except for mortality due to complications associated with the operation (Dabel et al. 2003). A LIMA bypass to the left descending coronary artery in particular has long-term patency rates. Also, when the LIMA 
was used instead of the saphenous vein for grafting to the LAD artery, positive effects on long-term morbidity and mortality were reported (Crouch et al. 1999). When the GSV was used as the graft material, it was reported to provide a higher flow capacity than the in situ LIMA (Fichelle et al. 2010). Histologically, the LIMA contains fewer smooth muscle cells and has a more elastic structure (Tennant and McGeachie 1990). Anastomosis of the left ITA to the RIA in coronary bypass operations is the preferred anastomosis (Fukui et al. 2010); it is accepted world-wide as the "gold standard".

\section{Radial artery}

Conventional CABG surgery utilizes a combination of arterial and venous grafts. However, the radial artery (RA) as a coronary artery bypass graft has also grown over recent years. Because endothelial function is preserved in RA grafts (Verma et al. 2004). The RA was initially used for coronary revascularization by Carpentier and colleagues in 1971 (Carpentier et al. 1973). But, 2 years later, its use was abandoned because of an occlusion rate that was greater than that observed in saphenous vein grafts. In 1992, Acar and colleagues indicated that the RA is a reasonable alternative to other types of conduits to complement the LIMA (Acar et al. 1992).

RA use is safe in patients with moderate to severe left ventricular dysfunction (Fazel et al. 2003) and in patients over the age of 65 (Modine et al. 2002). Since RA grafts have a capable of autoregulating its size to adapt to the target coronary circulation, as was compared with GSV grafts and left internal mammary artery graft (Chong et al. 2006). Finally, heart surgeons should keep in mind that the RA should be limited to grafting native vessels with a high degree of stenosis $(>70 \%)$ because of graft sensitivity to competitive flow and its increased propensity to spasm (Maniar et al. 2002).

\section{Veins}

The saphenous vein, used as the graft material in coronary artery bypass operations, belongs to the group of superficial veins (Tennant and McGeachie 1990). There are two main superficial veins in the lower extremities, the vena saphena magna and vena saphena parva. Since they are located above the membranous superficial fascia and not in the skeletal muscle, these superficial veins lack supporting tissue (Gartner and Hiatt 1997; Lafleur et al. 2003). The vena saphena magna originates from the dorsal venous arch as the continuation of the v. marginalis medialis in the dorsal part of the foot. It passes the anterior side of the malleoli, proceeds inside the calf, and, after passing through the posteromedial segment of the popliteal cavity, reaches the interior aspect of the femur (Tennant and McGeachie 1990). Then it goes upwards and flows into the femoral vein in the fossa ovalis at the superficial inguinal level. The vena saphena magna is connected to the deep venous system and the vena saphena parva through the v. perforans. The branch that is critically involved in the formation of varicose masses, and flows into the vena saphena magna, is the posterior arch vein (also known as the Leonardo vein), which drains three Cockett's perforator vein groups (Taggart et al. 2001).

\section{Vena saphena magna graft}

The distal or proximal saphenous vein is commonly used for coronary artery bypass operations. The saphenous vein is preferred in grafting because its femoral segment is larger and it has a thick surface. J. Kunlin was the first to use the saphenous vein as the graft material in femoropopliteal bypass in different locations in 1950 (Kunlin et al. 1950). The quality, length, histological structure, and the status of its endothelial cells all contribute to the usefulness of the saphenous vein as a graft material (Crouch et al. 1999)]. The success of the saphenous vein as the graft material in aorto-coronary bypass is reported to depend on the presence of perivenous fat and lack of traumatic injury (Erenturk 1997). It has also been noted that the administration of papaverine to the peripheral tissues around the saphenous vein increased its patency (Kocailik et al. 2008). Venous grafts are used in a variety of locations. A femoropopliteal bypass can be used in the reverse direction, or in the same direction after the valves are removed (Erenturk 1997; Alrawi et al. 2001). Furthermore, the great saphenous vein or the small saphenous vein, as well as veins taken from the arm, can be used as graft materials for vessels around the tibia, ankle, and foot. The saphenous vein has become indispensable as graft material for hepatic-renal, iliorenal and aorto-coronary bypasses, when it is available for use (Kelsall et al. 2005). It is also the graft material of choice in cases of carotid narrowing where endarterectomy is not possible (Norman and Litwack 1997). No-touch techniques have been developed to remove the saphenous vein with as little injury as possible. Uninjured saphenous veins with a diameter of $5 \mathrm{~mm}$ taken from the tibial area and including as few valves as possible are preferred as high-quality graft materials (Kelsall et al. 2005; Plass et al. 2010). Studies evaluating the effects of neuropeptides including substance $\mathrm{P}$, vasoactive intestinal peptide, calcitonin gene-related peptide, neuropeptide $\mathrm{Y}$ and somatostatin on the human saphenous vein showed many effects on vascular tonus and these effects were endotheliumdependent (Luu et al. 1992). Further studies are suggested to explore how these effects can increase the performance of graft materials in bypass operations.

\section{Comparison of grafts in terms of biochemical composition}

Until two decades ago, the autogenous greater saphenous vein (GSV) was the most popular graft material in 
bypass surgery for atherosclerotic coronary artery disease, despite the common occurrence of atherosclerotic events in the post-operative period. However, recent studies have reported that, owing to its long-term patency or the late development of atherosclerotic lesions, the internal mammary artery (IMA) could be the best alternative for revascularization (Erenturk 1997; Sisto et al. 1990). The later development of atherosclerotic lesions in the IMA than in the saphenous vein has been attributed to the difference in biochemical compositions of the two vessels (Table 1).

The endothelial cells of arteries have a greater capacity to secrete endothelium-dependent relaxation factors (EDRF) than those of veins. The main functions of EDRF include endothelium-dependent relaxation, prevention of vasospasms, and protection against intravascular thrombus formation and atherogenesis. The endothelium has the capacity to synthesize nitric oxide (NO), prostacyclin $\left(\mathrm{PGI}_{2}\right)$, endogenous vasoactive or inactive products (angiotensin-1 and bradykinin), endothelin-1, and endoperoxides (prostacyclin $\mathrm{H}_{2}$ and thromboxane $\mathrm{A}_{2}$, which are constriction factors) (Kocailik et al. 2008). The endothelium of the IMA spontaneously secretes more NO than that of the GSV (Oku et al. 1990). NO, a vasodilator inhibits thrombocyte adhesion and aggregation and is critical for maintaining the patency of the vessel lumen (Kocailik et al. 2008). Furthermore, the IMA contains more elastic lamina in its tunica media

Table 1 Comparison of some biochemical compositions of internal mammary artery and greater saphenous vein grafts (Skwarek et al. 2006; Sisto et al. 1990; Hwang et al. 2012; Oku et al. 1990; Vanhoutte 1997); Aydin 2011; Aydin et. al 2012

\begin{tabular}{|c|c|c|}
\hline Molecules & $\begin{array}{l}\text { Internal mammary } \\
\text { artery (IMA) }\end{array}$ & $\begin{array}{c}\text { Greater saphenous } \\
\text { vein (GSV) }\end{array}$ \\
\hline Heparan sulfate & High & Low \\
\hline Dermatan sulfate & Low & High \\
\hline Esterified cholesterol & High & Low \\
\hline Free cholesterol & High & Low \\
\hline Collagen & Low & High \\
\hline Phospholipids & High & Low \\
\hline DNA & High & Low \\
\hline Protein & High* $^{*}$ & Low \\
\hline Total GAG & High & Low \\
\hline Hyaluronic acid & High & Low \\
\hline $\begin{array}{l}\text { Chondroitin } \\
\text { sulfate }(A+B)^{*}\end{array}$ & High & Low \\
\hline Nitric oxide (NO) & High & Low \\
\hline Salusin-a & Low & High \\
\hline Salusin- $\beta$ & High* $^{*}$ & Low \\
\hline Apelin-36 & High* & Low \\
\hline
\end{tabular}

*High, but not significant. than other arterial grafts or the GSV. The greater sensitivity of the IMA than the GSV to vasoactive materials is believed to be the reason for its better patency rate (Erenturk 1997; Sisto et al. 1990).

Veins are more vulnerable than arteries to vasoactive substances and cannot work under high pressure. Additionally, while vein walls are supplied by vasa vasorum, arterial walls are supplied by both the lumen and vasa vasorum. Veins secrete vasoactive substances in very different kinds and amounts from arteries (Tennant and McGeachie 1990; Gartner and Hiatt 1997; Lafleur et al. 2003). The peptides apelin and salusin, for instance, are reported to be produced in larger quantities in the aorta and LIMA than in the saphena. Salusins suppress ventricular performance and exert inotropic and chronotropic effects (Skwarek et al. 2006; Vanhoutte 1997; Aydin et al. 2012). It has been claimed that salusin $\beta$ influences cardiac output more strongly than other well-known factors such as atrial natriuretic peptide or NO (Kocailik et al. 2008). These substances, which are produced in larger amounts in the arteries, could help to explain why artery grafts last longer than saphenous grafts. The major finding in support of this hypothesis is that synthetic grafts, which lack these peptide hormones, are less durable than biological grafts.

Biological grafts synthesize many substances including cholesterol, hyaluronic acid, heparan sulfate, dermatan sulfate, collagen, apelins and salusins (vasodilators). Collagen is the main structural connective tissue protein in blood vessels. The development of atherosclerosis leads to an increase in the amount of collagens in the artery walls. In the IMA, collagen constitutes between 25 and $40 \%$ of the total protein (Sisto et al. 1990). The fact that coronary arteries contain more collagen than the IMA suggests a predisposition to atherosclerosis. Of the total protein in the saphenous veins, $65 \%$ is collagen, which is much more than in arteries, another possible reason why the IMA is advantageous over the saphena (Sisto et al. 1990). Furthermore, the IMA contains less free cholesterol than the saphena. Since less cholesterol implies postponement of atherosclerosis, this could be another advantage of using the IMA. Likewise, the IMA contains more heparan sulfate than the saphena (Erenturk 1997). As heparan sulfate is associated with the bases of the cell membranes, arteries possess more cellularity than veins. In contrast, there is more derma$\tan$ sulfate in GAGs in the saphena than the LIMA. Since dermatan sulfate has a greater affinity for LDL and VLDL than other GAG components, veins are more predisposed to atherosclerosis than arteries (Sisto et al. 1990). Since the IMA secretes more prostacyclin than the SVG, platelet adhesion and activation, and vasospasms, are prevented in the former, and the root cause of atherosclerosis and graft occlusion is eliminated 
(Erenturk 1997). Another reason why the IMA graft is advantageous is that the diameter of this graft is compatible with the diameters of the coronary arteries. Thus, not only is turbulence eliminated, but also the incidence of thrombus development is reduced (Skwarek et al. 2006; Vanhoutte 1997). In consideration of the differences in composition between these arteries and veins, when biological grafts are going to be used for coronary bypass surgery, care should be taken to avoid injury to the endothelial layers of the vessels, where bioactive materials are synthesized. Any disruption of this layer will reduce the success of the graft. It is believed that if the cells synthesizing bioactive hormones are totally destroyed, the success rate of grafting will theoretically fall to that of synthetic grafting (Skwarek et al. 2006).

From a histopathological perspective, intimal hyperplasia, the first phase of atherosclerosis, is caused by smooth muscle cells that pass through the defects in the lamina elastica interna and invade the tunica intima. Therefore, the lamina elastica interna plays a key role in the artery wall structure, and its continuity along the vessel wall forms a barrier preventing the invasion of smooth muscle cells (Tennant and McGeachie 1990; Gartner and Hiatt 1997; Lafleur et al. 2003). This feature also makes the IMA advantageous over the GSV. However, pressure applied during harvesting of the saphenous vein graft in coronary artery bypass surgery decrease the patency (Ozturk et al. 2013).

In summary, currently most centers use the left internal thoracic (mammary) artery (LITA or LIMA). In contrast to SV grafts, the IMA displays growth potential in children with Kawasaki disease (Suda et al. 2000). IMA also has atherosclerosis preventive effects on native coronary artery which was grafted (Otsuka et al. 2013). The anastomosed site stenosis with IMA had selfhealing potential and showed improved clinical outcomes. Early adaptation of ITA after CABG within a few weeks was also obtained. Arterial grafts are being increasingly used in place of the SV to avoid the late complications of vein graft atherosclerosis and restenosis. (Otsuka et al. 2013).

\section{Conclusion}

Despite advances in technology and much hard work in the field, it has not been possible to develop graft materials that can replace natural materials. Although vein grafts are used commonly in coronary artery bypass surgery, the ideal graft material is the autologous LIMA. The ten-year patency rates range between 80 and $90 \%$ for the IMA and 40 and 55\% for the SVG (Erenturk 1997). The difference can be explained by the different amounts of biochemical molecules in the grafts such as cholesterol, collagen, and heparan sulfate, as well as the histological compatibility and diameters of the vessels
(Sisto et al. 1990; Hwang et al. 2012; Oku et al. 1990; Vanhoutte 1997). This review presents the most recent histological and biochemical data showing that IMA is the best choice in coronary bypass surgery, and could serve as a guide for heart surgeons.

\section{Competing interests}

The authors declare that they have no competing interests.

\section{Authors' contributions}

SA (First author) performed literature research, planned each sub-section and collaborated in the manuscript editing, SA (second author) wrote and reviewed the manuscript, MNE collaborated in the manuscript editing and was the guarantor of the integrity of the study with SA (First author). IS carried out the graphic design of figure. MY, MK and OG participated in the definition of intellectual content. All authors read and approved the final manuscript.

\section{Acknowledgments}

The authors thank Dr Tuncay Kuloglu for his helpful suggestions on draft versions of this paper.

\section{Author details}

${ }^{1}$ Elazig Research and Education Hospital, Clinic of Cardiovascular Surgery, Elazig 23119, Turkey. ${ }^{2}$ School of Medicine, Department of Anatomy, Firat University, Elazig 23119, Turkey. ${ }^{3}$ School of Medicine, Department of Medical Biochemistry (Firat Hormone Research Groups), Firat University, Elazig 23119, Turkey. ${ }^{4}$ School of Medicine, Department of Cardiovascular Surgery, Dicle University, Diyarbakir 21280, Turkey. ${ }^{5}$ School of Medicine, Department of Histology \& Embryology, Erzincan University, Erzincan, 24030, Turkey.

Received: 10 June 2013 Accepted: 13 November 2013 Published: 16 November 2013

\section{References}

About Arrhythmia [homepage on the Internet] (2012). http://www.heart.org/ HEARTORG/Conditions/Arrhythmia/AboutArrhythmia/AboutArrhythmia_UCM_002010_Article.jsp. Accessed: 27 Apr 2013

Acar C, Jebara VA, Portoghese M, Beyssen B, Pagny JY, Grare P, Chachques JC, Fabiani JN, Deloche A, Guermonprez JL (1992) Revival of the radial artery for coronary artery bypass grafting. Ann Thorac Surg 54(4):652-659

Alrawi SJ, Raju R, Alshkaki G, Acinapura AJ, Cunningham JN, Jr (2001) Saphenous vein endothelial cell viability: a comparative study of endoscopic and open saphenectomy for coronary artery bypass grafting. JSLS 5(1):37-45

Aydin S (2011) Effects of Cardiopulmonary Bypass on Expression of Apelin and Salusin and Investigation of whether or not they are Locally Synthesized in the Aorta, Saphenous Vein and Artery Graft. Specialization Thesis in Medicine. Dicle University, Diyarbakir, Turkey

Aydin S, Eren MN, Aydin S, Ozercan IH, Dagli AF (2012) The bioactive peptides salusins and apelin-36 are produced in human arterial and venous tissues and the changes of their levels during cardiopulmonary bypass. Peptides 37(2):233-239

Bleiziffer S, Hettich I, Eisenhauer B, Ruzicka D, Wottke M, Hausleiter J, Martinoff S, Morgenstern M, Lange R (2007) Patency rates of endoscopically harvested radial arteries one year after coronary artery bypass grafting. J Thorac Cardiovasc Surg 134(3):649-656

Carpentier A, Guermonprez JL, Deloche A, Frechette C, DuBost C (1973) The aorta-to-coronary radial artery bypass graft: a technique avoiding pathological changes in grafts. Ann Thorac Surg 16(2):111-121

Chong WC, Collins P, Webb CM, De Souza AC, Pepper JR, Hayward CS, Moat NE (2006) Comparison of flow characteristics and vascular reactivity of radial artery and long saphenous vein grafts. J Cardiothorac Surg 1:4

Creswell LL, Alexander JC, Ferguson TB, Lisbon A, Fleisher LA (2005) Intraoperative interventions: American College of Chest Physicians guidelines for the prevention and management of postoperative atrial fibrillation after cardiac surgery. American College of Chest Physicians Chest 128(2 Suppl):28S-35S

Crouch JD, O'Hair DP, Keuler JP, Barragry TP, Werner PH, Kleinman LH (1999) Open versus endoscopic saphenous vein harvesting: wound complications and vein quality. Ann Thorac Surg 68(4):1513-1516 
Cullen P, Rauterberg J, Lorkowski S (2005) The pathogenesis of atherosclerosis. Handb Exp Pharmacol 170:3-170

Dabel RJ, Goss JR, Maynard C, Aldea GS (2003) The effect of left internalmammary artery utilization on short-term outcomes after coronaryrevascularization. Ann Thorac Surg 76(2):464-470

Deppe AC, Liakopoulos OJ, Choi YH, Slottosch I, Kuhn EW, Scherner M, Stange S, Wahlers T (2013) Endoscopic vein harvesting for coronary artery bypass grafting: a systematic review with meta-analysis of 27,789 patients. J Surg Res 180(1):114-124

Elghobary T, Légaré JF (2010) What has happened to multiple arterial grafting in coronary artery bypass grafting surgery? Expert Rev Cardiovasc Ther 8 (8):1099-1105

Erenturk S (1997) Conduit choice for coronary bypass operation. GKD Cer Derg 5:145-155

Fazel S, Mallidi HR, Pelletier MP, Sever JY, Christakis GT, Goldman BS, Fremes SE (2003) Radial artery use is safe in patients with moderate to severe left ventricular dysfunction. Ann Thorac Surg 75(5):1414-1421

Ferrari ER, von Segesser LK (2006) Arterial grafting for myocardial revascularization: how better is it? Curr Opin Cardiol 21(6):584-588

Fichelle JM, Cormier F, Franco G, Luizy F (2010) What are the guidelines for using a venous segment for an arterial bypass? General review. J Mal Vasc 35(3):155-161

Fukui T, Tabata M, Manabe S, Shimokawa T, Takanashi S (2010) Graft selection and one-year patency rates in patients undergoing coronary artery bypass grafting. Ann Thorac Surg 89(6):1901-1905

Gartner LP, Hiatt JL (1997) Color Texbook of Histology. Saunders of Company WB, Philadelphia, pp 213-229

Hwang HY, Kim JS, Oh SJ, Kim KB (2012) A randomized comparison of the Saphenous Vein Versus Right Internal Thoracic Artery as a Y-Composite Graft (SAVE RITA) trial: early results. J Thorac Cardiovasc Surg 144(5):1027-1033

Kelsall CJ, Chester AH, Amrani M, Singer DR (2005) C-type natriuretic peptide relaxes human coronary artery bypass grafts preconstricted by endothelin-1. Ann Thorac Surg 80(4):1347-1351

Kocailik A, Basaran M, Ugurlucan M, Ozbek C, Kafali E, Yerebakan C, Selimoglu O, Banach M, Ucak A, Ogus TN, Us M (2008) Papaverine solution improves preservation of saphenous vein grafts used during cardiac surgery. Acta Cardiol 63(4):445-449

Kunlin J, Bitry-Boely C, Volnie B (1950) Remarks on aortography. Rev Chir 69(9-10):286-298

Lafleur MA, Handsley MM, Dylan RE (2003) Blood vessel structure. Expert Reviews in Molecular Medicine:5. Accession information: Vol. 5; 22 September 2003 Cambridge University Press

Luu TN, Chester AH, O'Neil GS, Tadjkarimi S, Yacoub MH (1992) Effects of vasoactive neuropeptides on human saphenous vein. Br Heart J 67(6):474-477

Lytle BW, Blackstone EH, Loop FD, Houghtaling PL, Arnold JH, Akhrass R, McCarthy PM, Cosgrove DM (1999) Two internal thoracic arterygrafts are better than one. J Thorac Cardiovasc Surg 117(5):855-872

Maniar HS, Sundt TM, Barner HB, Prasad SM, Peterson L, Absi T, Moustakidis P (2002) Effect of target stenosis and location on radial artery graft patency. J Thorac Cardiovasc Surg 123(1):45-52

Miller Yl, Choi SH, Fang L, Tsimikas S (2010) Lipoprotein modification and macrophage uptake: role of pathologic cholesterol transport in atherogenesis. Subcell Biochem 51:229-251

Modine T, Al-Ruzzeh S, Mazrani W, Azeem F, Bustami M, Ilsley C, Amrani M (2002) Use of radial artery graft reduces the morbidity of coronary artery bypass graft surgery in patients aged 65 years and older. Ann Thorac Surg 74(4):1144-1147

Murray G (1953) Blood vessel surgery. Can Med Assoc J 69(3):296-299

Norman AW, Litwack G (1997) Hormones, 2nd edition. Academic, California, USA, pp 418-420

Oku T, Yamane S, Suma H, Satoh H, Koike R, Sawada Y, Takeuchi A (1990) Comparison of prostacyclin production of human gastroepiploic artery and saphenous vein. Ann Thorac Surg 49(5):767-770

Otsuka F, Yahagi K, Sakakura K, Virmani R (2013) Why is the mammary artery so special and what protects it from atherosclerosis? Ann Cardiothorac Surg 2(4):519-526

Ozturk N, Sucu N, Comelekoglu U, Yilmaz BC, Aytacoglu BN, Vezir O (2013) Pressure applied during surgery alters the biomechanical properties of human saphenous vein graft. Heart Vessels 28(2):237-245
Plass CA, Podesser BK, Prusa AM (2010) Effect of blower-mister devices on vasoreactivity of coronary artery bypass grafts. J Thorac Cardiovasc Surg 140(4):923-927

Risteski PS, Akbulut B, Moritz A, Aybek T (2006) The radial artery as a conduit for coronary artery bypass grafting: review of current knowledge. Anadolu Kardiyol Derg 6(2):153-162

Sabik JF, Stockins A, Nowicki ER, Blackstone EH, Houghtaling PL, Lytle BW, Loop FD (2008) Does location of the second internal thoracic artery graft influence outcome of coronary artery bypass grafting? Circulation 118(14 Suppl):S210-S215

Sisto T, Ylä-Herttuala S, Luoma J, Riekkinen H, Nikkari T (1990) Biochemical composition of human internal mammary artery and saphenous vein. J Vasc Surg 11(3):418-422

Skwarek M, Grzybiak M, Kosiński A, Hreczecha J (2006) Basic axes of human heart in correlation with heart mass and right ventricular wall thickness. Folia Morphol 65(4):385-389

Smith S, Beasley M, Hodes R, Hall H, Biel E, Huth EW (1957) Auxiliary myocardial vascularization by prosthetic graft implantation. Surg Gynecol Obstet 104 (3):263-268

Suda Y, Takeuchi Y, Ban T, Ichikawa S, Higashita R (2000) Twenty-two-year followup of saphenous vein grafts in pediatric Kawasaki disease. Ann Thorac Surg 70(5):1706-1708

Taggart D, D'Amico R, Altman D (2001) Effect of arterial revascularisation on survival: a systematic review of studies comparing bilateral and single internal mammary arteries. Lancet 358(9285):870-875

Tennant M, McGeachie JK (1990) Blood vessel structure and function: a brief update on recent advances. Aust N Z J Surg 60(10):747-753

Vanhoutte PM (1997) Endothelial dysfunction and atherosclerosis. Eur Heart J 18(Suppl E):E19-E29

Verma S, Szmitko PE, Weisel RD, Bonneau D, Latter D, Errett L, LeClerc Y, Fremes SE (2004) Should radial arteries be used routinely for coronary artery bypass grafting? Circulation 110(5):e40-e46

doi:10.1186/2193-1801-2-612

Cite this article as: Aydin et al:: The cardiovascular system and the biochemistry of grafts used in heart surgery. SpringerPlus 2013 2:612.

\section{Submit your manuscript to a SpringerOpen ${ }^{\odot}$ journal and benefit from:}

- Convenient online submission

- Rigorous peer review

- Immediate publication on acceptance

- Open access: articles freely available online

- High visibility within the field

- Retaining the copyright to your article

Submit your next manuscript at $>$ springeropen.com 